\title{
About Royal Manors from the Late Iron Age in Middle Sweden
}

\author{
David Damell
}

\begin{abstract}
How royal power arose in Sweden and how this affected the creation of the State, has always been the focus of discussion among scientists and laymen. This is certainly because royal power can be connected to some of the most important ancient monument areas in the country such as Gamla Uppsala, Adelsö hovgård etc. In these areas there are visible remains of monuments and cemeteries as well as remains of terraces, plateaus etc.

How these royal seats were formed is at present unknown. Excavations in many of these ancient momument areas during the last decade have, however, shown that the royal seats were constructed in a certain pattern. In this regard the excavated royal seats at Gamla Uppsala, Fornsigtuna, Adelsö hovgård and Husby-Enhörna are the only seats addressed in the paper. Each of these seats has strong similarities with one another. It seems possible though to start future excavations of other royal seats based upon the results described in the paper.
\end{abstract}

David Damell, Örebro läns museum, Box 314, S-701 46 Örebro, Sweden.

How royal power arose in our country and how it may have contributed to the formation of the Svea State - Sweden - has always been a question of great interest to scholars as well as to the general public. The so-called Västgöta-school is living proof of this interest.

The royal power is connected with some of our most distinguished ancient monuments such as Old Uppsala, Adelsö Royal Manor etc (Ambrosiani 1985). This connection between power and specific places may be studied in historical sources. But also the time before written sources points to this connection, for example the connection between certain placenames and certain types of ancient monuments such as big mounds (Hyenstrand 1989).

The connection between royal power and big mounds has certainly also been studied by an older generation of scholars. Those scholars tried to connect older traditions or mythical stories directly to certain burial places of known kings or chiefs (Lindqvist 1936; Nerman 1941). Burial mounds, excavated as well as unexcavated ones, have so to speak played a role in research. Any attempt to seek knowledge about settlement patterns of probable royal manors has, however, not been carried out until recently. To seek detailed knowledge about these special places must now be considered as important as continuing the more general studies. In this way we can find out whether the places actually served as royal manors, and if so when they were established, how they were designed and used etc.

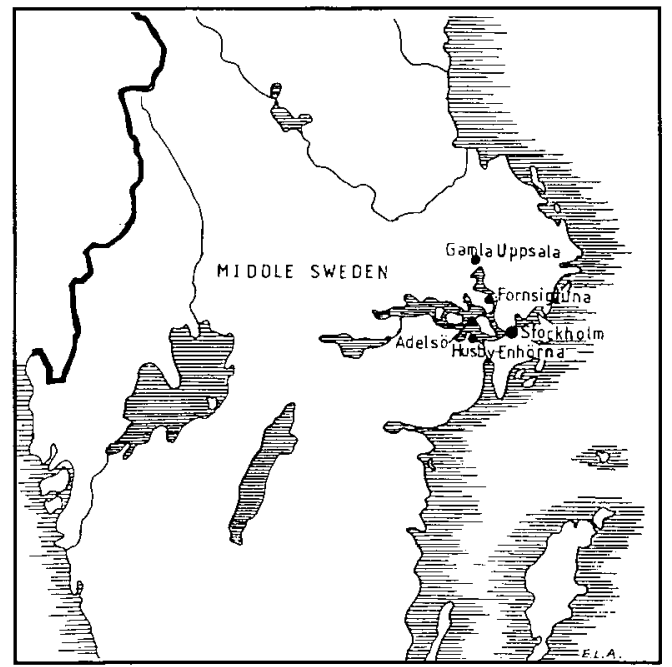

Fig. 1. Map of middle Sweden with the four royal manors mentioned in the article marked. Drawing by Emilia Latuer-Andersson. 


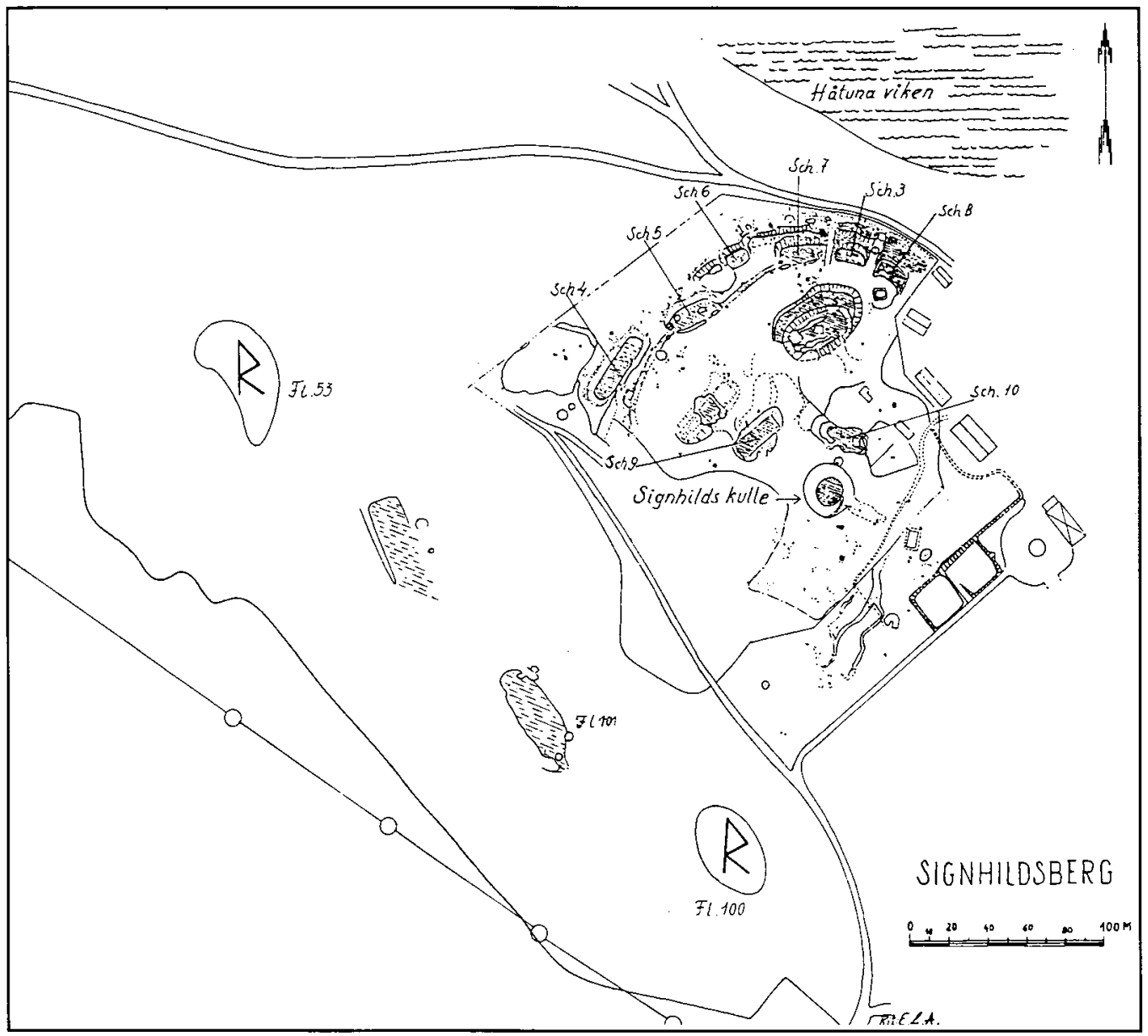

Fig. 2. The ancien monument area at Fornsigtuna just near the estate Signhildsberg. Map by $G$ Winberg and $R$ Rydén. Drawing by Emilia Lauer-Andersson.

After that it is of course possible to return to a more general view, which means a study of the royal manors from a perspective of state formation. Let us begin with Fornsigtuna, situated at the estate of Signhildsberg in Håtuna parish, Uppland, near Lake Mälaren and not far from the old town Sigtuna. Immediately north-west of the manor there is a large area covered with ancient remains around a meadow.

The $5 \mathrm{~m}$ level shows a shallow lagoon just north of this area. The monuments can be described as follows:

One mound $27 \mathrm{~m}$ in diameter and $2-3 \mathrm{~m}$ high with a flat top. The mound is called
Signhild's mound. Then two house-plateaus, 12 house-terraces, one rectangular stone-setting, one cemetery with 10 round stone-settings and one with 10 triangular, boat-formed and round stone-settings.

Most of the house-terraces are situated at the $8 \mathrm{~m}$ level and in connection with stoneconstructions, probably remains of landingstages. In the southern part of the monument-area some remains of a medieval village are visible.

The whole area was mapped by the Central Board of National Antiquities in 1983-1985. There are also other cemeteries within the boundaries of the estate Signhildsberg. 
It is known that the estate Signhildsberg in older times, before 1678 was named Fornsigtuna (Old Sigtuna). The name Fornsigtuna is first mentioned about 1170 . In a letter from the pope Alexander to the Swedish king and his earl (Knut Eriksson and Birger Brosa) the latter are told to give back three estates to the archbishop, taken from him when the diocese was moved from the town of Sigtuna to Uppsala in the 1160 s.

It is probable that the king in connection with this took back property which earlier had been donated to the church during the mission era, perhaps by King Stenkil (Hult 1989:49ff). Fornsigtuna is also mentioned by Snorre Sturlasson (about 1220) as the place where Odin first settled in Sweden and where the pagan cult was practised. Also in 1299 Fornsigtuna is mentioned in a letter by the Swedish king Birger Magnusson. It is also mentioned in 1315 in connection with the royal family.

It seems quite clear from all this that Fornsigtuna was a royal estate, originally a socalled Uppsala öd-farm. Also later Fornsigtuna is mentioned in assessments from the 16-th century.

In 1627 Fornsigtuna was donated by the Swedish king Gustav II Adolf to a nobleman. In 1678 a new manor-house was finished at Fornsigtuna and from that time the estate had a new name, Signhildsberg, from an old Nordic tale about Signhild and Habor.

All this means that it is a fact that the estate Signhildsberg in ancient times was Fornsigtuna, the precursor of Sigtuna (Damell 1989:22ff; v Friesen 1923; Malmberg 1923).

The aims of the archaeological excavations at Fornsigtuna were to make a map of the place, to date the remains and to investigate the continuity of the settlement and the functions of the place. As mentioned above, the mapping was done 1983-1985. Also phosphate-mapping was done. After that, excavations began in 1984. So far field-work has been carried out for 5 months. The field-work is now finished. Only small trenches were investigated in eight of the house-terraces. In Signhild's mound as well as in the two big house-plateaus larger trenches were excavated.

The mound was first believed to be a motte, but the walls found in the top of the mound were very late, the remains of a summerhouse visible on a map from 1817.

Under the walls there was a cairn of a type common in burials. But there was no burial there, only the remains of a dark cultural layer without objects and dated to the early Roman Iron Age by $\mathrm{C} 14$. Also a ramp in connection with the mound gave early datings, in that case to the pre-Roman Iron Age.

So it was proved that the mound was not originally built as a burial mound or a motte. What I now think is that Signhild's mound was originally erected as a court-mound, due to the similitaries with known court-mounds such as one (Domarehögen) at Old Uppsala and other parallels. Court-mounds were used as judge's seats in very old times. It is probable, though not fully proven, that this mound was built in connection with the house-plateaus mentioned above. The excavation at the smaller house-plateau, ca $30 \mathrm{~m}$ long, was done by means of two big trenches, one in the middle of the plateau and one in the eastern part.

The excavation has shown that the plateau is built artificially of a big heap of stone on top of a small hill. The plateau was then covered with clay, sand and soil which composed the floor in a big long-house $9 \times 25 \mathrm{~m}$ in size, an area of $225 \mathrm{~m}^{2}$. There were two rows of postholes and the walls were slightly curved, a very typical construction during the Viking Period. The artifacts found are nails along the walls, arrowheads (not the hunting type), potsherds, a fragment of a bronze ornament, glass beads, bone material etc. The dating is to the Viking Period.

There are also seven C14-datings from AD $490 \pm 75$ to AD $950 \pm 190$, and one from AD $1420 \pm 90$. Most of the C14-datings show the Viking Period.

The other house-plateau is contructed in exactly the same way as the one mentioned above, but it is much bigger. This house was 
$40 \times 10$ m large - a huge building. We know that this very dominant building dates from the Viking Period, judging from the artifacts and C14- and TL-datings. It is also worth mentioning that this large building is situated near the entrance-road to the whole estatecomplex.

The two plateau-buildings must have dominated the whole area, and hence it is clear that they played a special role here during the Viking Period. As mentioned above eight houseterraces were also investigated by means of small trenches. In all cases the remains of buildings could be observed, with cultural deposits and artifact material very typical for the late Iron Age. Also from the terraces there are C14-datings, the oldest AD $340 \pm 85$, but mainly within the time span from AD 610 to AD 955.

In 1988 the remains of a rectangular building, $9 \times 9 \mathrm{~m}$ large was also excavated. It was impossible to date this foundation properly but from the construction it seems quite clear that it must belong to the same time as the plateau-buildings as a part of the whole complex. The function of this building also remains unclear but it seems probable that it was a store-house, a very typical building in a complex like this.

The phosphate-mapping was done in a coordinate-system at every $20 \mathrm{~m}$. The samples were taken at a depth of $30 \mathrm{~cm}$. The phosphate map shows very clearly that there is much phosphate in connection with the house-foundations and also within the area where the medieval village seems to have been situated.

Also osteological analyses were made. The results show that there are similarities between Fornsigtuna and Birka with regard to the mixture of different animal bones. A complete analysis of the artifact material has not yet been done. Most of the material seems in fact to be connected with the building constructions, such as nails etc. But there are also parts of ornaments, a bronze weight, arrowheads, beads, pottery etc. The material is general, but it is also very typical for the late Iron
Age, especially the Vendel and Viking Periods. The results of the excavations so far are very good in relation to the aims mentioned above.

The examination has shown that there is a quite clear continuity within the place at least from the early Iron Age.

It might be that the excellent conditions for communication at this place made it a natural meeting-point for cult and jurisdiction for a larger area during the early Iron Age. It is possible that the court-mound was erected already at this time, but it is more probable that the mound is younger because of the similarity with the house-plateaus seen from a constructional point of view. Sometime during the shift between the Roman Iron Age and the Migration Period the first house-terraces seems to have been erected. From that time on they must have been used continuously until the 10 th century.

All these results rest mainly on C14-analysis. But also the artifact material is datable especially to the Vendel and Viking Periods. The oldest object from this place is a glass bead dated to the Migration Period. C14datings and dated objects seem to point to a more intense activity within this place from the Migration Period onwards. This can be interpreted as an indication that the activities at the old court and cult place gradually expanded to include for example markets.

Quite soon a growing central-power in the province of Uppland was established at the place in order to get influence and control, above all over the economy. A royal site was etablished. This must have happened during the Vendel Period when the house-plateaus were erected. There is so much work behind this establishment that it seems probable that there was an intention of supreme power behind it. Also the dominant position in the terrain must be interpreted in the same direction. The two plateaus are so similiar that I believe they are the work of the same architect. My theory is that the royal hall was situated on the smaller plateau and the garrison in the hall on the big plateau near the 


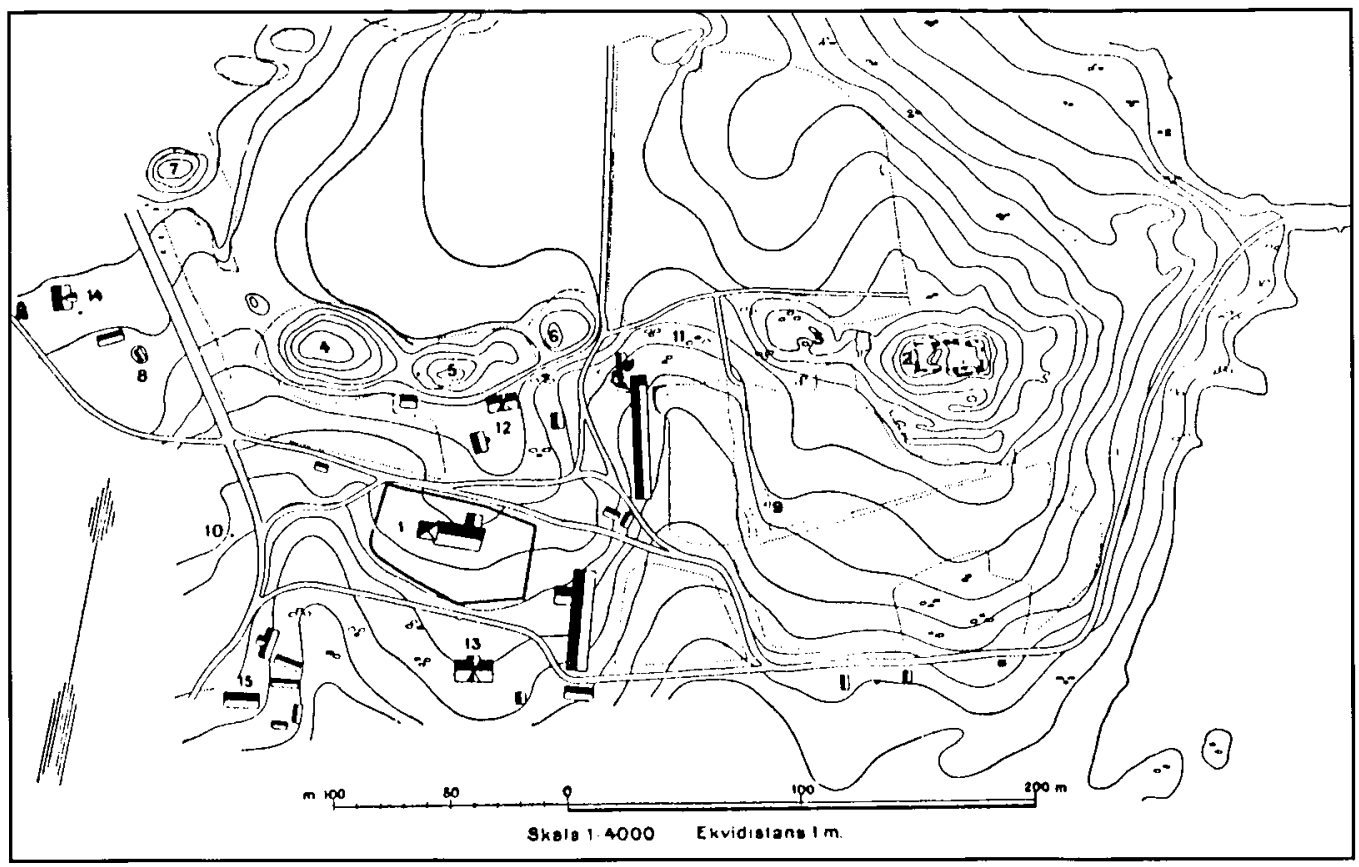

Fig. 3. The Adelsö complex with the ruins of Alsnö hus (no 2), burial molunds (no 4-7) etc. After Thordeman 1920.

entrance-road to the estate-complex. It is also clear from historical sources that Fornsigtuna was once a royal site. This place, then, must have been used as a royal site until the end of the 10th century, when among else the good harbour conditions just north of Fornsigtuna were silted up by land elevation. This fact and the necessity of creating a new place for the new religion, Christianity, caused the king (probably Erik Segersäll) to build a new town for market and cult ceremonies on land belonging to the Crown but not far away from the old central place. The new town also got its name from the old place, as a sign that the old supreme power was now moved to a new place.

The old estate was then donated to the bishop of Sigtuna in the 11 th century, but when the diocese moved to Uppsala the Crown took back its old property (Ambrosiani 1985; Damell 1989:28ff).

The next important place is Adelsö hovgård (Adelsö Royal Manor) on the island of Adelsö in Lake Mälaren. The ancient monument area at Adelsö hovgård consists of the ruins of Alsnö hus, some other medieval building remains, three burial-mounds (King's mounds), a runic inscription on a boulder, a so-called court-mound, the burial mound Skopintull and a lot of terraces, probably man-made, to the east and north-east of the Alsnö hus ruins. The latter are the remains of King Magnus Ladulås' palace from the later part of the 13 th century, excavated by Bengt Thordeman (Thordeman 1920) who at the time also registered some other remains of medieval buildings in the ground to the west and south of Alsnö hus. In connection with Thordeman's excavations deposits of Viking Age context were also found, above all in a terrace straight east of the ruin but also just to the west and north of the big medieval foundation (Rydh 1936:186 ff). No constructional details were found on that occasion but the find material, consisting of fragments of Arabian coins, beads of glass and cornelian, iron arrowheads, parts of a bone comb and potsherds is typical Viking Age.

Direct information about the character and size of the Viking Age dwellings was not 


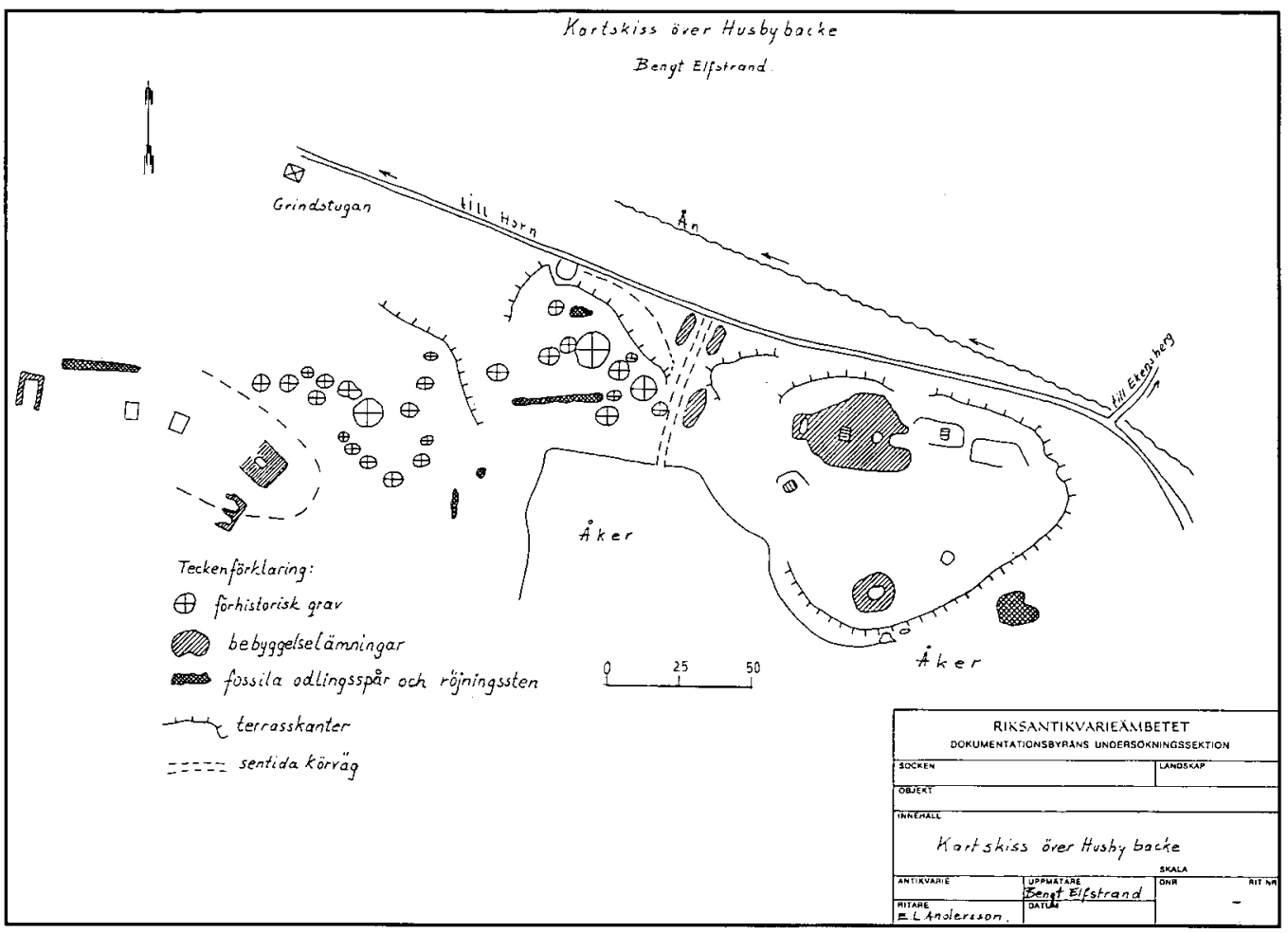

Fig. 4. Husby-Enhörna with building remains, grave-mounds etc. Map by B Elfstrand. Drawing by Emilia Lauer-Andersson.

possible to get from the very limited excavation. Topographically the Adelsö complex is very similar to that of Fornsigtuna, situated as it is on the top of a dominating promontory well visible and with a vast view over Lake Mälaren and with the adjacent Viking town of Birka within sight.

One hypothesis is that the town of Birka was founded under the protection of Adelsö Royal Manor, in the same way as Sigtuna was founded under the protection of Fornsigtuna Royal Manor. In order to study some questions about the origin of the prehistoric royal manor, its size and appearance, its relation to other royal manors and to the town of Birka, new excavations begun at the site last summer (1991). Of course the medieval layers on the site will be analysed at the same time, as will the connection between the royal manor and the neighbouring Adelsö Church. It is also important to point out that the rich finds from the burial mound Skopintull, excavated by
Hanna Rydh (Rydh 1936: 104 ff) and situated within the ancient monument area of the royal manor, underline the importance of the site as early as the Viking Age. The very rich finds must be interpreted as remains of royal burials datable to the 10th century.

If we go southwest from Adelsö to Överenhörna parish in the province of Södermanland we find the remains of another royal manor which has been partly excavated in recent years, namely Husby-Enhörna at present-day Ekensberg Manor. The estate got its name in the 17th century after the governor Bengt Ekehjelm. He got the estate from the State, which had owned it since the so-called Västerås recess of 1527 . The older name was Husby. During the 13th century Husby belonged to Duke Erik, a son of Birger Jarl, but later it belongs to the cathedral of Strängnäs. Before that Husby must have been royal property. Within the ancient monument area, Husby backe, Bengt Elfstrand in collaboration 
with the Husby-Enhörna Foundation excavated several building remains showing that the site had been used continuously from the Viking Period until the 17 th century.

The place is very similar to both the earlier described places, situated on a former Mälaren bay. A big plateau, probably artificial, dominates the site. Around it several house-foundations were found. Just to the west of this complex there are several Iron Age burials and some more building remains, probably from the late Iron Age/Medieval Period. A small harbour must have belonged to the site. Notable among the oldest finds are an amber bead, a glass bead, potsherds, fragments of loom weights, knives, nails etc.

The design of Husby-Enhörna is thus very similar to that of Adelsö hovgård, with a plateau for house-foundations dominating the landscape in a communication position and well visible from the Lake Mälaren bay at that time.

Just like at Adelsö there is a church nearby, Överenhörna Church, in direct connection with the royal manor. At both places, as at Old Uppsala, the churches originally must have served as royal manor churches. Fornsigtuna, which was abandoned as a royal manor already during the Viking Age, does not have a church.

But the most distinguished royal manor of all was that of Old Uppsala, or rather Uppsala, as the site was called before the name was transferred from the old place to the town Östra Aros when the diocese moved from the cathedral of Old Uppsala to the new town. This happened during the later part of the 13th century. Ancient monuments and finds from Old Uppsala are carefully described by Sune Lindqvist (Lindqvist 1936) and therefore there is no reason to discuss them in detail here. It is well known that the ancient monument area consists of three huge royal mounds, two of them excavated, a big grave-field to the south of the royal mounds, a court-mound and the so-called royal manor terraces north of the church (today only the chancel of the old cathedral remains).
Not until very recently were excavations carried out on the courtmound and the royal manor terraces under the leadership of Else Nordahl (Christiansson \& Nordahl 1989). The trial excavation on the top of the court-mound showed that it was built in a way very similar to that of the court-mound at Fornsigtuna, with a stabilizing stone layer covered by a thin layer of gravel and sand which is covered by clay under a sandy turf layer, the surface of the construction. There are no traces of burials or other activities in the construction. From my point of view it is therefore probable that this mound originally was built as a platform for the court, then as a court-mound. It has not yet been possible to date the courtmound. The upper royal manor terrace (pla-

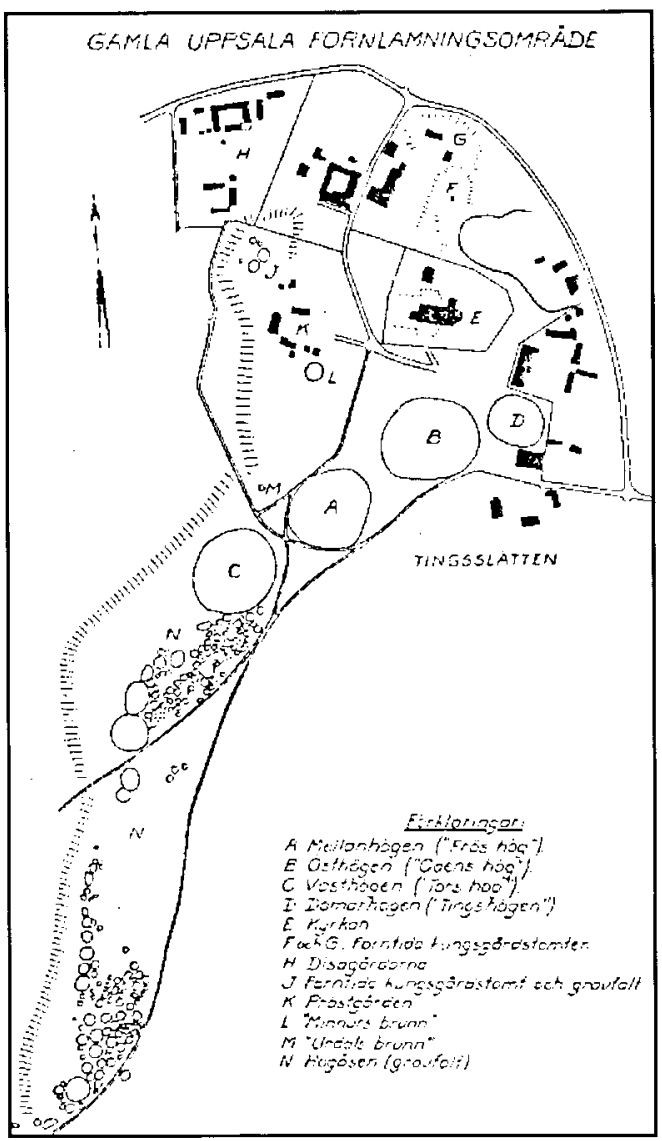

Fig. 5. Old Uppsala with the royal mounds (A-C), the court-mond $(D)$, the church $(E)$ and the royal manor terraces $(F-G)$. After Lindquist 1936. 
teau) just north of the church was shown to be artificially built already in the excavations by Sune Lindqvist. It was built of a $2.5 \mathrm{~m}$ thick layer of clay, and on the top of this plateau there was once a huge building, a hall, at least $10 \mathrm{~m}$ wide. The length is still unknown. The only dated artifact so far is an iron brooch from the 8th century.

It is also proven that a probable prehistoric cultural layer can be found within the churchyard and also under the church. It is also important to mention that Viking Age boatgraves have been excavated in recent years just south of the Old Uppsala vicarage.

The royal manor area of Old Uppsala also shows topographical similarities with the earlier described sites, above all with Fornsigtuna and Adelsö hovgård. Artificially built houseplateaus in landscape dominating situations, the presence of so-called court-mounds and good conditions for communication are significiant features. The latter also applies to Husby-Enhörna.

I have now briefly described four excavated royal manors in middle $S$ weden. Of course the places mentioned are only a small part of the total number of prehistoric royal manors. But they are the only sites so far excavated which give special attention to dating and design and for this reason they are important models for future studies of the remaining material from a chronological point of view as well as from an architectural one. It seems clear that a special design formed the royal manors described here, maybe a traditional layout of the state building complexes already during the late Iron Age. A certain chronological agreement seems to exist, too, even though the time of establishment seems to be certain only for the buildings at Fornsigtuna, where there are Vendel Period datings for the bottom layers of the plateaus. At Old Uppsala the foundation period may be older (Migration Period in the two excavated royal mounds) while Adelsö hovgård may very likely be contemporary with Fornsigtuna. So far Husby-Enhörna seems to belong to the Viking Period.

Another similarity between Old Uppsala, Adelsö hovgård and Fornsigtuna is that towns have been founded nearby, certainly under the protection of the king. I am thinking of Östra Aros (present-day Uppsala), Birka and Sigtuna. Perhaps it is also a fact that the royal manors discussed here were established along the important trade routes by a central power of increasing strength, which in the course of time created supreme power over smaller kingdoms and chiefdoms in the region. This may be the first sign of a state formation created by increasing economical and political control over smaller areas which no longer were able to resist the power of the main king. 


\section{REFERENCES}

Ambrosiani, B. 1985. Aristocratic Graves and Manors in Early Medieval Sweden. Archaelogy and Environment 4. Umeả.

Christiansson, H. \& Nordahl, E. 1989. Tingshögen and Kungsgårds-platåcrna in Gamla Uppsala. Tor. Vol. 22.

Damell, D. 1989. Fornsigtuna. Avstamp - för en ny Sigtuna-forskning. Sigtuna Museer.

v. Friesen, O. 1923. Om staden Sigtunas ålder och uppkomst. Upplands formminnesförenings tidskrift 37. 1922-23. Uppsala.

Hult, B. 1989. Strom, fornsitune et Guazbro. Sigtunastiftets biskopsbord. Avstamp-foren ny Sigtuna-forskning. Sigtuna Museer.

Hyenstrand, А. 1989. Sverige 989. Makt och herravälde l. Stockholm Archaeological Reports nr 24.
Lindqvist. S. 1936. Uppsala högar och Ottarshögen. Stockholm.

Malmberg, E. 1923. Signhildsberg, Håtuna socken, Håbo härad, Uppsala län. Svenska slott och herresäten. Stockholm.

Nerman, B. 1941. Sveriges rikes uppkomst. Stockholm. Rydh, H. 1936. Förhistoriska undersökningar påAdelsö. Stockholm.

Thordeman, B. 1920. Alsnö hus. En svenskt medeltidspalats i sitt konsthistoriska sammanhang. Stockholm. See also:

Damell, D. 1991. Fornsigtuna. En kungsgairds historia. Stiftelsen Upplands-Bro fornforskning. Tierp. 
